\title{
THE POSITION OF LEIVU
}

\author{
Petri Kallio \\ University of Helsinki, FI \\ petri.kallio@helsinki.fi
}

\begin{abstract}
Leivu has generally been connected with Võro and especially its Hargla dialect. However, this classification has always been based on superficial synchronic similarities rather than a rigorous diachronic analysis. Instead, closer examination shows that Leivu is the earliest offshoot of South Estonian and that its similarities with Hargla Võro can better be explained by their geographical proximity.
\end{abstract}

Keywords: historical linguistics, Finnic languages, South Estonian, Võro, Leivu

DOI: https://doi.org/10.12697/jeful.2021.12.2.05

\section{Introduction}

As Sulev Iva (2015) has recently pointed out, Leivu differs from Lutsi and Kraasna in the sense that Leivu can be difficult to understand even for a native Võro speaker. Yet Leivu has generally been connected with Võro and especially the geographically closest Hargla dialect (see T. Iva 2007 for the most recent overview of Leivu studies). ${ }^{1}$ Ferdinand Johann Wiedemann (1868: 502) mentioned this idea already, even though Heikki Ojansuu (1912: 15-18) was the first to formulate the

1 Leivu has even been called "a Hargla Estonian dialect between Alūksne and Gulbene/ Latvia" (Dahl \& Koptjevskaja-Tamm 2001: XIX), which must be taken for a misunderstanding of some sort. Then again, the only quantitative study so far discussing all of South Estonian connected Leivu with Lutsi and Kraasna (Wiik 1999 based on the atlas by Toomse 1998). This result reminds me of another even more recent quantitative study no less unexpectedly connecting Livonian with Votic and Ingrian (Honkola et al. 2019 based on Tuomi 2004-2010). Hence, there seems to be a problem with the quantitative studies based on dialect atlases whose main purpose is to show representative rather than exhaustive isoglosses. What is representative is always subjective, thus making the most peripheral languages and dialects suffer the most from wrong linguistic classifications (i.e., peripheral geographically and/or to a researcher's interest). 
theory of the Leivus as the early 17th century migrants from Hargla and possibly Karula. The present article provides an update to the discussion on the linguistic position of Leivu within Inland Finnic, that is, the South Estonian subgroup of Finnic.

\section{South Estonian archaisms in Leivu}

\subsection{Phonology}

What makes Leivu look South Estonian at first glance are its phonological archaisms such as the affricates inherited from Proto-Finnic (Kallio 2007: 241-242, 2014: 157-158, 2018b: 122-123):

- Proto-Finnic *cika > Finnish sika, Karelian sika, Veps siga, Votic sika, Estonian siga, Livonian siga $\sim$ Võro tsiga, Leivu tšiga 'pig'.

- Proto-Finnic *conki- > Finnish sonkia, Karelian tšonkie, Veps čonkta, Estonian songima $\sim$ Võro tsunǵma, Leivu ts" onǵma 'to grub'.

- Proto-Finnic *keüci > Finnish köysi, Karelian keysi, Votic tšöüsi, Estonian köis, Livonian kieuž Võro kö̈dś, Leivu käüdž 'rope'.

- Proto-Finnic *süci > Finnish sysi, Karelian sysi, Votic süsi, Estonian süsi, Livonian $s i$ ’ž $\sim$ Võro hüdsi, Leivu üdži '(char)coal'.

Another South Estonian archaism also preserved in Leivu is the diphthong *äi (Kallio 2018a: 261-262, 2018b: 123): ${ }^{4}$

- Proto-Finnic *säičcen, *säicceme- > Finnish seitsemän, Karelian seittšemen, Veps seičeme, Votic seitsee, Estonian seitse, Livonian seis Võro säidse, Leivu säidze 'seven'.

2 Both Karelian and Veps can irregularly have affricates which, however, were never due to $* i>* c i$ contrary to those in South Estonian, thus suggesting that they were of different origin (Kallio 2007: 241-242, 2014: 157-158).

3 As tempting as it would be to consider Leivu vocalism as an archaism (cf. Proto-Uralic

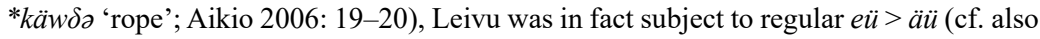
Võro lö̈̈dmä $\sim$ Leivu läüdmä 'to find').

4 I used to think aloud that elsewhere in Finnic the following dental obstruent caused *äi > $* e i$, but Anthony Jakob (p.c.) has now far more convincingly suggested that $* \ddot{a} i>*_{e i}$ was regular everywhere except for monosyllabic vocalic stems and disyllabic $\ddot{a}$-stems (see the data in Kallio 2018a: 261-262). 
- Proto-Finnic *väicci > Finnish veitsi, Karelian veittši, Veps veič, Votic veittsı, Estonian veits, Livonian veis Võro väitś, Leivu väitš 'knife'.

The diphthong *ai was preserved not only in South Estonian including in Leivu - but also in Livonian (Kallio 2014: 159-160, 2018a: 257-259, 2018b: 123-124):

- Proto-Finnic *haina > Finnish heinä, Karelian heinä, Veps hein, Votic einä, Estonian hein Livonian äina, Võro hain, Leivu ain 'hay'.

- Proto-Finnic *saina $>$ Finnish seinä, Karelian seinä, Veps sein, Votic seinä, Estonian sein Livonian sāina, Võro sain, Leivu sain 'wall'.

- Proto-Finnic *saisa- > Finnish seisoa, Karelian seisuo, Veps seišta, Votic sõisõa, Estonian seisma Võro saisma, Leivu saizma 'to stand'.

- Proto-Finnic *saibas/*taibas > Finnish seiväs, Karelian seiväs, Veps seibaz, Votic seiväz, Estonian teivas $\sim$ Livonian tāibaz, Võro saivas, Leivu saavas 'pole'.

Finally, there are two cases where in this respect Leivu looks more "South Estonian" than all the rest of South Estonian (Kallio 2018b: 124-126):

- Proto-Finnic *haimo > Finnish heimo, Karelian heimo, Veps heim, Votic õimo, Estonian hõim $(\rightarrow$ Võro hõim $) \sim$ Livonian aim, Leivu aim 'tribe'.

- Proto-Finnic *laipa $>$ Finnish leipä, Karelian leipä, Veps leib, Votic leipä, Estonian leib $(\rightarrow$ Livonian lēba, Võro leib) Leivu laib 'bread'.

As early as the 16th and 17th century, Old Literary South Estonian already had the forms leib and höim (whose $\langle\ddot{\mathrm{o}}\rangle=/ \tilde{\mathrm{o}} /$ ), which could hardly be considered anything other than North Estonianisms. Since Old Literary South Estonian was primarily based on the Tartu dialect (Pajusalu 2006: 89-92), one could still regard Leivu as an early 17th century offshoot of Võro (cf. Ojansuu 1912: 16-18), but only if one further assumed that by that time North Estonian leib and hoim had merely spread to Tartu but not yet to Vorro. Then again, as the Lutsi and Kraasna forms were already leib and hõim, the separation of Leivu must be dated much earlier than those of Lutsi and Kraasna (cf. Ojansuu 1912: 21-26). 


\subsection{Morphology}

As is well-known, South Estonian has two conjugations, namely $\varnothing$ - and $s$-conjugations (Pajusalu 1996: 49-56), which, however, only differ in the active indicative third person (Ikola 1931, Posti 1961). The $\varnothing$-conjugation has preserved the original Proto-Finnic third person endings:

- Prs. sg3: Proto-Finnic *teke > Võro tege, Leivu tiege 'does'.

- Prs. p13: Proto-Finnic *tekebät > Võro tegeväq, Leivu tiegevä? 'do'.

- Pst. sg3: Proto-Finnic *teki > Võro tegi, Leivu tiegi 'did'.

- Pst. pl3: Proto-Finnic *tegit > Võro teiq; NB. Leivu tiekki < ProtoFinnic *tekihen (cf. the $s$-conjugation below).

The $s$-conjugation was in turn based on the Proto-Finnic reflexive endings originally only occurring in the third person (Lehtinen 1984: 39-41, Koivisto 1989):

- Prs. sg3: Proto-Finnic *eläksen > Võro eläs, Leivu 'elass 'lives'.

- Prs. p13: Proto-Finnic *eläkset > Võro eläseq, Leivu 'elaze? 'live'.

- Pst. sg3/p13: Proto-Finnic *elihen/*elihet $>$ Võro elli (q), Leivu ${ }^{i} e l l i$ 'lived'.

As far as morphology is concerned, the most striking South Estonian archaism going back as far as Proto-Uralic is indeed the present tense third person singular with no ending, whereas the present marker *-pi ( $>*_{-}$bi after unstressed syllables) is used everywhere else in Finnic (Viitso 2003: 144, Kallio 2014: 156):

- Proto-Finnic *teke $>$ Coastal Finnic *teke $+*_{-}-p i=* t e k e b i>$ Finnish tekee, Karelian teköy, Veps tegeb, Votic teeв, Estonian teeb (cf. analogically Livonian $t \bar{\imath}$ 'eb pro $†$ tiegūb) 'does'.

5 The expected outcome of the Proto-Uralic present tense third person singular *teka would of course have been Proto-Finnic $†$ teki, since second-syllable *a yielded $*_{i}$ wordfinally (Kallio 2012: 171-172). Proto-Finnic *teke was therefore due to the analogy of the other present forms (cf. 1sg *tegen, 2sg *teget, 1pl *tegemmä, 2pl *tegettä, 3pl *tekebät), not least because tteki would have been identical with the past tense third person singular. Anyway, *teke pro tteki cannot be used as evidence that *-pi was just secondarily lost in South Estonian (cf. Kettunen 1962: 85). 
Although *-pi has been expansive enough to spread from North Estonian to Mulgi, Tartu, and even Võro (Toomse 1955, 1998: 47, 100), ${ }^{6}$ it still often co-occurs with the $\varnothing$ - and $s$-conjugations (Tanning 1961: 49, Keem 1970: 23, 25, 27-28, Pajusalu 1996: 108-110). This somewhat reminds me of Old Literary Finnish where - $p i$ almost freely varied with zero (cf. Mikael Agricola's saa = saapi 'gets' and even teke = tekepi 'does'), as if it had not been a grammatical ending but an enclitic particle (cf. Nikkilä 1985: 285-327).

\section{South Estonian innovations in Leivu}

\subsection{Phonology}

As far as linguistic classifications are concerned, shared innovations are far more important than shared archaisms. For instance, the fact that Finnish and Võro share $a \sim \ddot{a}$ harmony does not make them any more closely related languages, because $a \sim \ddot{a}$ harmony goes back all the way through Proto-Finnic to Proto-Uralic. Thus, neither the affricates nor the diphthongs are equally strong evidence for the South Estonianness of Leivu as the assimilations ${ }^{*} p t / *_{k t}>*_{t t},{ }^{*} p c /{ }^{*} k c>{ }^{*} c c,{ }^{*} p s /{ }^{*} k s>{ }^{*} s s$, etc. (Kallio 2007: 236-237, 2014: 156-157, 2018b: 126-127):

- Proto-Finnic *oksa > Finnish oksa, Karelian oksa, Veps oks, Votic õhsa, Estonian oks, Livonian oksā $\sim$ Võro oss, Leivu "oss 'branch'.

- Proto-Finnic *ükci > Finnish $y k s i$, Karelian $y k s i$, Veps $\ddot{u} k s$, Votic ühsi, Estonian üks, Livonian ikš Võro ütś, Leivu ütšs 'one'.

- Proto-Finnic *ükteksän > Finnish yhdeksän, Karelian yheksän, Veps ühesa, Votic ühesää, Estonian üheksa, Livonian '̄'dõks Võro üte(s) $s a$, Leivu ütese 'nine'.

6 According to Karl Kont (1954: 1, 11), even Leivu had the ending *-pi, but only in monosyllabic vocalic verb stems of which his examples were diup 'drinks' and š́ûp 'eats' (cf. also jûub 'drinks'; Ojansuu apud, Toomse 1955: 8). However, the examples given by Valter Niilus $(1936: 18,25,26,28)$ were $d \hat{u}$ 'drinks', $\dot{s} \hat{\dot{u}}$ 'eats', $t \hat{u}$ (sic, recte $t \hat{u}$ ) 'brings',

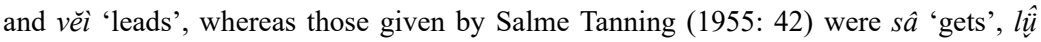
'hits', $l \hat{\imath}$ 'lays an egg', and $t \hat{u}$ 'brings' in spite of the fact that she partly used the same informants as Kont did. 
South Estonian innovations involving consonant clusters also include $*_{t n}>* V n$ and $* k n>* n n$, similarly shared by Leivu (Viitso 2003: 144, 147, Kallio 2018b: 127-128):

- Proto-Finnic *litna $>$ Finnish linna, Karelian linna, Veps lidn, Votic lidna, Estonian linn $(\rightarrow$ Salaca Livonian linn $) \sim$ Võro liin, Leivu lein '(walled) town'?

- Proto-Finnic *näknüt $>$ Estonian näinud, Livonian $n \bar{a} n d \sim$ Võro $n a ̈ n-$ nüq, Leivu nännü (cf. analogically Finnish nähnyt, Karelian nähnyt, Veps nähnu, Votic nähnü) 'seen'.

The metathesis $*_{n h} / * l h / *^{*} h>* h n / * h l / * h r$ was yet another South Estonian consonantal innovation well reflected by Leivu, whereas the North Estonianism ${ }^{*} n h /{ }^{*} l h /{ }^{*} r h>*_{n} / *^{*} / *^{*}$ often dominated in more northern South Estonian (Kallio 2014: 162, 2018b: 128-129):

- Proto-Finnic *tarha $>$ Finnish tarha, Karelian tarha, Veps tarh, Votic tara, Estonian tara, Livonian tarā $\sim$ Võro tahr, Leivu tahr 'enclosure'.

- Proto-Finnic *vanha $>$ Finnish vanha, Karelian vanha, Veps vanh, Votic vana, Estonian vana ( $\rightarrow$ Võro vana), Livonian vanā $\sim$ Kraasna vahn, Leivu vahn 'old'.

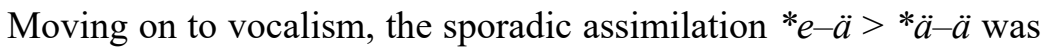
otherwise shared by South Estonian and Livonian (Kallio 2014: 158159, 2018b: 130), ${ }^{8}$ but Leivu again stands as a partial exception:

- Proto-Finnic *kenkä > Finnish kenkä, Karelian kenkä, Veps keng, Votic tšentšä, Estonian king Livonian käanga, Võro käng Leivu k'eng 'shoe'.

- Proto-Finnic *selkä > Finnish selkä, Karelian selkä, Veps selg, Votic seltšä, Estonian selg Livonian sälga, Võro sälg, Leivu sälg 'back'.

7 Courland Livonian nīnõ 'castle' and Salaca Livonian ninn 'town' were apparently due to the sporadic assimilation $* l-N>*_{n-N}$ (cf. also Proto-Finnic *lehmä $>$ Courland Livonian nī'em, Salaca Livonian niem 'cow').

8 True, Old Livonian strangely shows both $\ddot{a}$ and $e$ (Wiedemann 1861: 35, 97, Winkler \& Pajusalu 2009: 97, 174). One may of course wonder whether $e$-vocalism was analogically generalised from the umlauted partitive plurals kengi and selgi. Still, this could only explain the word for 'shoe' frequently occurring in the plural, whereas the word for 'back' would remain a mystery. 
Contrary to Mulgi keńg and selg, Leivu $k^{i} e n g$ can in no way be regarded as a North Estonianism for obvious geographical reasons. Either Leivu $k^{\prime}$ eng was influenced by Latvian k, kenge itself borrowed from Finnic, or Leivu $k^{i}$ eng goes back directly to Proto-Finnic *kenkä, thus meaning that *kenkä $>* k \ddot{a} n k \ddot{a}$ never spread to Leivu, although

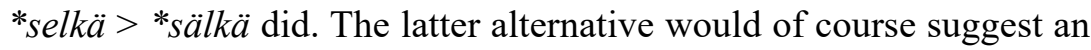
early separation of Leivu. In addition to the sporadic assimilation $*_{e-\ddot{a}}$ $>* \ddot{a}-\ddot{a}$, South Estonian and Livonian often also shared the sporadic backing $* e-\ddot{a}>* \ddot{e}-a$ (Viitso 2003: 146-147, Kallio 2018b: 130-131):

- Proto-Finnic *meccä > Finnish metsä, Karelian mettšä, Veps mec, Votic mettsä, Estonian mets $\sim$ Livonian mõtsā, Võro mõts, Leivu mõts 'forest'.

- Proto-Finnic *nenä> Finnish nenä, Karelian nenä, Veps nena, Votic nenä, Estonian nina Võro nyna, Leivu nõna 'nose'. ${ }^{9}$

However, the most characteristic South Estonian innovation involving vocalism was the raising of first-syllable overlong mid vowels in monosyllabic words or before an open second syllable (Teras 2003: 26-33, Viitso 2003: 174-177). As the raising long remained phonetic (viz. $\left.{ }^{*} e e / * \ddot{o} \ddot{o} / * o o / * \tilde{o} \tilde{o}>*_{e} e / *^{*} \ddot{o} / *_{0} o / * \tilde{o} \tilde{o}\right)$, there were still no traces of it in 16th and 17th century Old Literary South Estonian (Kallio 2018b: 129). Yet the raising was no doubt a common South Estonian innovation, as demonstrated by the following modern South Estonian alternation pairs (i.e., overlong : long):

- Mulgi: ii/ii : ee, üü/üü: öö, uи/uи : oo, õ $: \tilde{o} \tilde{o}$ (EMS, Laande \& Todesk 2013).

- Tartu: $\hat{e}: \bar{e}, \hat{o}: \bar{o}, \hat{o}: \bar{o}, \hat{o}: \overline{\tilde{o}}$ (Wiedemann 1864: 4); i : ee, üü : öo, uи : oо, $\tilde{o} \tilde{o}: \tilde{o} \tilde{o}$ (EMS).

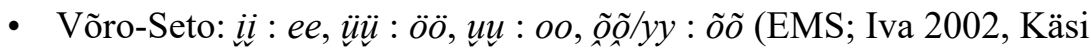
2011).

9 Livonian nanā as well as Sangaste Tartu and Karula Võro nana 'nose' would seem to go back to Proto-Finno-Saamic *nana (> North Saami njunni 'nose'), but at least in theory, their first-syllable vocalism could also have been influenced by Latvian $n \bar{a} s s$ 'nostril, nose'. 
- Leivu: $\hat{\imath}: \breve{\imath} \grave{e}, \hat{u}: \breve{u ̈ o}, \hat{u}: \breve{u} o, \hat{e}: \hat{e} / e ̨$ (Niilus 1935: 191-196); $\hat{\imath}:$ ie, $\hat{u}$ : üo, $\hat{u}:$ uo, $\bar{e}: \dot{e} e$ (Kettunen apud Niilus 1939: 6-7); ii : ie, üü : üo, uu : uо, õ $\tilde{o}: \tilde{o} \tilde{o}$ (EMS).

Interestingly, although everywhere else in South Estonian the contracted vowels were also subject to this raising, Leivu provides yet another exception (Viitso 2009: 274-275):

- Proto-Finnic *tegen > Võro tiii Leivu tie 'do' (1SG).

- Proto-Finnic *veden > Võro vii $\sim$ Leivu vie 'water' (GEN).

Here we might very well be dealing with different relative chronologies again suggesting an early separation of Leivu:

- Leivu: $*_{e e}>*_{e e}$ before $*_{e} e>*_{e e}$.

- Elsewhere: $*_{e} e>*_{e e}$ before $*_{e e}>*_{e e}$, thus also $*_{e} e>*_{e e}>*_{e e}$.

The raising of $\tilde{o} \tilde{o}$ was a special case, because there was no corresponding high vowel phoneme. In general, the difference between [r:] and [u:] is harder to hear and pronounce than those between [e:] and [i:], [ø:] and [y:], or [o:] and [u:]. For instance, Valter Niilus gave two alternative genitives for Leivu mêk 'sword', mẹga and meęga (1935: 193), the former suggesting the merger of $\tilde{o} \tilde{o}$ and $\tilde{o} \tilde{o}$, but the latter suggesting the diphthongisation of $\tilde{o} \tilde{o}$ (cf. Kettunen's e e above).$^{10}$ Elsewhere, however, he also mentioned the adessive meggat (Voolaine \& Niilus 1936: 7 = Mets et al. 2014: 44), pointing to the common South Estonian alternation pair $\tilde{o} \tilde{o}: \tilde{o} \tilde{o}$. On the other hand, raised $\tilde{o} \tilde{o}$ also often went unheard, as exemplified by a 1956 recording in which the word for 'fresh' was originally transliterated as rếsk (Tanning 1956: 1-2) but more recently as rì skk (Mets et al. 2014: 94-95).

10 Remarkably, in both Leivu and Livonian, long mid vowels were diphthongised but not long mid-high vowels, though only in Leivu the latter were due to the raising of overlong vowels, whereas in Livonian they were due to umlaut (Viitso 2009: 273-274; Kallio 2016: 59). Incidentally, it has universally been taken for granted in Baltic linguistics that East Baltic $* \bar{e}_{1}\left(>\right.$ Lithuanian $\dot{e}$, Latvian $e$ ) was lower than $* \bar{e}_{2}(>$ Lithuanian/Latvian $i e$ ), which was neither raised nor umlauted ${ }^{*} \bar{e}_{1}$ but due to the monophthongisation of stressed $*_{e i} /{ }^{*} a i$ (Stang 1966: 44-46, 52-68). Since the diphthongisations in heavily Latvianised Leivu and Livonian hardly occurred independently of that in Latvian itself, East Baltic $*_{e_{2}}$ was most likely a long mid vowel similar to Finnic $*_{e e}$ (i.e., IPA [e:]), whereas East Baltic $*_{\bar{e}_{1}}$ was apparently mid-low (i.e., IPA [æ:]). 


\subsection{Morphology}

Perhaps the most striking morphological innovation shared by all of South Estonian is the inessive ending $*_{-} h n A$ corresponding to $*_{-S S A}$ almost everywhere else in Finnic. Both endings co-occur only in the South Ostrobothnian dialect of Finnish where $-s\left(<*_{-S S A}\right)$ is used elsewhere except for the following two groups (Laurosela 1913: 141-146):

- Certain monosyllabic pronominal stems: mihnä 'where' (INT), johna 'where' (REL), kuhna 'in whom', kehnä 'in whom'; rarely muhna 'in me', suhna 'in thee'.

- Before a possessive suffix: tuvahnani 'in my room', tuvahnas 'in thy room', tuvahnansa 'in his/her/its/their room', tuvahnamma 'in our room', tuvahnanna 'in your room'.

The original West Uralic inessive ending was no doubt ${ }_{\text {-snA }}$ (see most recently Ylikoski 2016). Lauri Posti (1953: 67-69) already suggested that $*_{s n}>*_{s s}$ took place after an unstressed syllable, whereas $*_{s n}>* h n$ took place after a (primary or secondary) stressed syllable. As this only explains the first group, I would like to suggest a minor correction: ${ }^{*} n>*_{s S}$ between an unstressed syllable and a word-final syllable, $*_{s n}>* h n$ elsewhere (cf. other sibilant + resonant clusters; Aikio 2015: 44). Eventually either $*_{-s S A}$ or *-hnA was analogically generalised, and even South Ostrobothnian has not completely been spared from analogies (cf. täs 'here', tuas 'there', etc.). What makes South Estonian unique within Finnic is the fact that *-sSA was not generalized but *-hnA (Toomse 1998: 93, 133, Pajusalu et al. 1999: 89-92):

- Old Literary South Estonian, Mulgi, Tartu, West Võro, Nirza Lutsi, Leivu $-n$.

- Hargla and Rõuge Võro - $h n$.

- East Võro, Seto, Pilda Lutsi, Kraasna - $h$.

The distribution of $-h n$ is larger in the case of monosyllabic words as well as certain adverbs which can sometimes even retain - $h n A$ (cf. Seto aohna 'in time', iihnnä 'in front'; Keem \& Käsi 2002: 41). In any case, Leivu once again proves to be genuine South Estonian. 


\section{Võro-Seto innovations in Leivu?}

In general, Vorro-Seto is characterised by its conservatism compared to more North Estonianised Mulgi and Tartu, although we already saw that even Võro-Seto has its own North Estonianisms (cf. hõim and leib above). Still, there were also exclusively Võro-Seto innovations, the most prominent of which was the raising of first-syllable short mid vowels before a nasal (Keem \& Käsi 2002: 33, Kallio 2018a: 255, 2018b: 135-137):

- Inland Finnic *emä > Mulgi emä, Tartu emä, Võro-Seto imä, Leivu 'ema 'mother'.

- Inland Finnic *om > Mulgi om, Tartu om, Võro-Seto um $(\sim \mathrm{om})$, Leivu "om 'is'."

- Inland Finnic *sëna > Mulgi sõna, Tartu sõna, Võro-Seto sõna/syna, Leivu sõna 'word'.

Only Vorro-Seto (including Lutsi and Kraasna) was subject to the raising $e / \ddot{o} / o / \tilde{o}>i / \ddot{u} / u / \tilde{o}$, whereas Leivu was subject to the breaking $e / o>{ }^{i} e /{ }^{\prime} O$ having nothing to do with the following consonant (cf. ${ }^{i} e z a$ 'father', $k^{u}$ oda 'house'; Niilus 1935: 168-171, 181-183). Since Leivu failed to take part in the signature Vorro-Seto innovation $e / 0 / o / \tilde{o}>i / u ̈ / u / \tilde{o}$, there is no justification to call Leivu a dialect of Vorro(-Seto). Particularly revealing is the word for 'tomorrow':

- Old Literary South Estonian: hômen (Gutslaff 1648) > hommen (Wastne Testament 1686).

- Mulgi: ommen (EMS, Laande \& Todesk 2013).

- Tartu: ommen, except Sangaste ommõn (EMS).

- Võro-Seto: hummõń (EMS, Iva 2002, Käsi 2011); NB. Lutsi hum̌męn, Kraasna hummen (Mets et al. 2014).

- Leivu: uomen, uomõn (EMS); ŭòmen (Niilus 1935: 181); uòmęn (Mets et al. 2014).

11 The Proto-Finnic present forms were $1 \mathrm{sg} *$ olën, $2 \mathrm{sg} *$ olët, $3 \mathrm{sg} *$ on, $1 \mathrm{pl}$ *olëmma, $2 \mathrm{pl}$ *olëtta, 3pl *omat. In Inland Finnic, 3sg *om pro *on was due to the analogy of $3 \mathrm{pl}$ *omat, whereas later in Võro-Seto, $o$-vocalism has largely been generalised throughout the paradigm: 1sg olõ, 2sg olõt, 3sg um, $1 \mathrm{pl}$ olõmi, $2 \mathrm{pl}$ olôti, $3 \mathrm{pl}$ ummaq $\rightarrow 1 \mathrm{sg}$ olõ, $2 \mathrm{sg}$ olot, 3sg om, 1pl olõmi, $2 \mathrm{pl}$ olõti, 3pl ommaq. 
As the Proto-Finnic form was *hoomënna (> Finnish huomenna, Karelian huomena, Veps homen, Votic oomõnna), Standard Estonian homme no doubt goes back to hoome still found in Western and Insular Estonian. Judging from the Old Literary Estonian data, the shift hoome $(n)>$ homme(n) took place as recently as the 17th century in both North and South Estonian. Still, its distribution covered all of South Estonian, the only exception being Leivu. Meanwhile, Lutsi and Kraasna were subject to hoome(n)>homme(n) as well as e/ö/o/õ > $i / \ddot{u} / u / \tilde{o}$, suggesting that both were still spoken in or near Võru County during the 17th century. Even though e/ö/o/o $>i / u ̈ / u / \tilde{o}$ cannot be dated as precisely as hoome $(n)>$ homme(n), it had certainly taken place by the 18th century (cf. "imma die Mutter (im Pölfwschen)"; Hupel 1780: 529). An even earlier date is possible, because in spite of the fact that Johann Gutslaff's grammar (1648) mainly deals with the Tartu dialect, it occasionally also includes suspiciously Võro-looking words, such as unno 'Mutterbruder' (cf. Tartu onu/ono Võro uno 'uncle'), apparently due to the fact that his daytime job was a pastor in Urvaste, Vorru County. The fact that homen and unno co-occur in his grammar is no problem, because pre-nasal e/ö/o/o $>i / u ̈ / u / o \tilde{c}$ could long have remained operative. Anyway, while Lutsi and Kraasna demonstrably belong to the Võro-Seto branch, Leivu does not.

\section{Hargla Võro innovations in Leivu?}

As noted above, the idea of the Hargla origin of Leivu goes back to Ferdinand Johann Wiedemann (1868: 502), although Heikki Ojansuu (1912: 15-18) was the one to turn this hypothesis into a theory. Yet Ojansuu offered no linguistic evidence either, but just noted that Hargla Võro and Leivu share a couple of relatively recent sound changes which he promised to reveal in his forthcoming South Estonian Lautgeschichte, regrettably never published due to his untimely passing. For this reason, the first scholar to actually list any linguistic parallels between Hargla Võro and Leivu was Salme Nigol (1955: 149-150). As brief as her list was, it primarily included similarities whose distribution is not restricted to Hargla Võro and Leivu, such as the analogical de-illative typical of Tartu and adjacent dialects (Tanning 1961: 42, Keem 1970: 39, Keem \& Käsi 2002: 40-41) as well as the present tense second person plural-turned-singular ending -de, well-attested elsewhere in 
Võro (Keem \& Käsi 2002: 47). ${ }^{12}$ In general, not every similarity matters when subgrouping languages, but the following criteria must be met:

1. The distribution criterion. - Not all similarities between Hargla Võro and Leivu matter, but only those shared by them alone, because otherwise nothing would stop us from taking any Common South Estonian innovation mentioned above as proof of a close relationship between Hargla Võro and Leivu.

2. The innovation criterion. - Only innovations matter, whereas archaisms do not. The fact that Hargla Võro and Leivu have wordfinally preserved consonant clusters like $k l$ (cf. kakl 'neck'), $k r$ (cf. $k a k r$ 'oat'), $p r$ (cf. sõpr 'friend'), etc. only proves that they are conservative, but not that they are closely related.

3. The genetic criterion. - Only genetic similarities matter, whereas areal similarities do not. As Hargla Võro is the most Latvianised Estonian dialect spoken outside Latvia (Vaba 1997: 483-486), it shares numerous Latvianisms with Leivu, though it may also have one Livonianism (cf. es $>$ is 'did not'; O'Rourke \& Pajusalu 2016: 72). Anyway, these at most show that Hargla Võro and Leivu are close neighbours, but not that they are close relatives.

4. The big picture criterion. - Only similarities matter, whereas "similarities" do not. Take the word for 'rope', Hargla Võro kä̈̈ds and Leivu kä̈üž, ostensibly suggesting that $e \ddot{u}>\ddot{a} \ddot{u}$ was shared by Hargla Võro and Leivu alone, since elsewhere in South Estonian we find köüds, köids, keids, etc. (EMS s.v. käüds, köüds). In Hargla Võro, however, e $\ddot{u}>\ddot{a} \ddot{u}$ is a sporadic change limited to this word, whereas in Leivu it occurs without exception (cf. Hargla Võro leüdmä Leivu läüdma 'to find'). Perhaps Leivu eü > äü was pushed by its diphthongisation $\ddot{u} \ddot{u}>\ddot{o u}$, related to its well-known Latgalianisms $i i$ $>e i$ and $u u>o u$. In any case, Hargla Võro käüds cannot be explained in this way, but at most it was borrowed from or influenced by Leivu kä̈̈dž, thus belonging to our areal similarities above.

12 The Proto-Finnic background of the Leivu present tense personal endings can be summarised as follows (cf. Pajusalu 1996: 104-120, S. Iva 2007: 81-86, Junttila 2018: 111-114): 1sg $-\varnothing<*_{-} n$; $2 \mathrm{sg}-d E \leftarrow 2 \mathrm{pl} ; 3 \mathrm{sg}-\varnothing \equiv$ (Ø-conjugation); 3 sg $-s s<*$-ksEn (s-conjugation); $1 \mathrm{pl} / 2 \mathrm{pl}-m E /-d E<*_{-}-m m A /{ }^{*}-t t A$, but vocalism generalised from the pronominal stems *me-/*te- 'we/you'; 3pl -vA? <*-bAt (Ø-conjugation); 3pl -zE?< ${ }^{*}$-ksEt (s-conjugation). 
Indeed, Anders Johan Sjögren (1850: 10) had already pointed out that there still existed a dialect continuum between Hargla Võro and Leivu as recently as the early 19th century. Thus, Leivu did not become surrounded by Latvian or, more precisely, Latgalian until even later, and many Leivus still kept on regularly visiting Võru County (Mela 2001: 29-32). The fact that Hargla Võro was in direct contact with Leivu for centuries is the main reason for their similarities which I am in no way denying (see, e.g., Teras 2010 for prosodic similarities).

\section{Leivu in the South Estonian family tree}

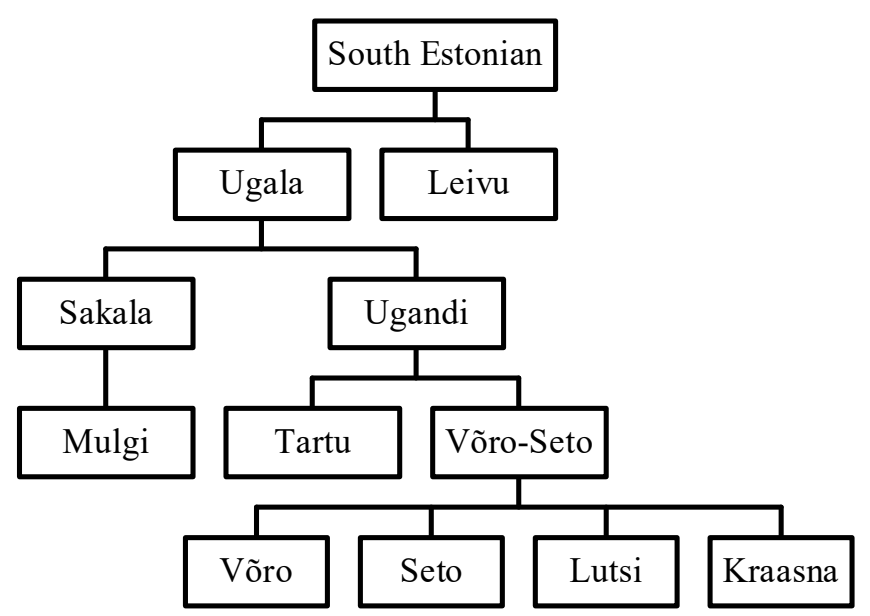

Figure 1. The South Estonian family tree.

Võro and Seto including Lutsi and Kraasna constitute the core of the South Estonian family tree, see Fig. 1. Yet their more precise interrelationships are difficult to display in tree form, not least because the sharpest dialect boundary within Võro-Seto does not run between Võro and Seto but between West and East Võro (Pajusalu 1999: 159-164). The position of Tartu and whether it is more closely related to Mulgi or Vorro-Seto can also be debated; thus far the latter relationship has been more popular (Rätsep 1989: 1509, Pajusalu et al. 2018: 50-54, 67-69). Due to the massive North Estonianisation of both Mulgi and Tartu, however, the dialect boundary between them is not as sharp as that between Tartu and Võro (Pajusalu 1999: 159-164), but this fact does not 
necessarily tell us all about the time depth. At least the dialect boundary between Mulgi and Tartu closely follows the border of the ancient counties of Sakala and Ugandi, hence my names for the pre-stages of Mulgi and Tartu-Võro-Seto, respectively. Even though Ugala has earlier been used synonymously with both Ugandi and South Estonian, my compromise is now to use Ugala as the name for the proto-stage between Ugandi and South Estonian.

The idea of Leivu as the earliest offshoot of South Estonian is based on several minor innovations shared by all the rest of South Estonian. While none of them alone is sufficient to prove anything, there are so many of them together that it cannot be a coincidence. Some of these innovations can be dated to or even before the 16th and 17th centuries based on Old Literary South Estonian, hence suggesting that by that time Leivu was already a distinct dialect. However, Leivu was only distinct but not distant, since it was still open to widespread innovations, such as the ga-comitative (Rätsep 1989: 1516). Needless to say, there is nothing contradictory in the idea that some later innovations covered the whole Estonian dialect continuum, whereas some earlier ones did not. On the contrary, nothing could be more typical of the linguistic history of Estonia. For instance, although North and South Estonian were already distinct dialects as early as the Iron Age, they share several medieval and even later areal innovations (Rätsep 1989: 1511-1515), because of which they may now appear more closely related to each other than they are (cf. Honkola et al. 2019: 178).

\section{The linguistic roots of Leivu}

The idea of Leivu as an early 17th century offshoot of Hargla Võro (Ojansuu 1912: 15-18) has long been challenged by the idea of autochthonous Leivu, namely that Leivu could be connected with the 12th century Ochela (Atzele) Chuds mentioned in the Novgorod First Chronicle (Ariste 1962: 271-273). Indeed, if we exclude the earliest, more or less fictional, chapters of the Primary Chronicle, the Chuds of the Old Slavic chronicles can almost always be identified with the South Estonians (Kallio 2015: 91-93). Even Salme Nigol (1970: 68) accepted the idea of autochthonous Leivu, thus indirectly implying that her listed similarities with Hargla Võro were after all areal. 
Remarkably, the number of Latvian loanwords is around 750 in Leivu as opposed to only around 180 in Lutsi (Vaba 1997: 38-39, 44-47). This fact does not prove but at least strongly suggests that the Latvian influence on Leivu was not only heavier but also considerably longer-lasting than that on Lutsi. Contrary to Leivu, Lutsi shares all the 17th century linguistic innovations with the rest of South Estonian, fully agreeing with the traditional theory of Lutsi as an early 18th century offshoot of East Võro (Ojansuu 1912: 18-26). Thus, there is no problem to date the Leivu separation from the rest of South Estonian centuries earlier.

Still, the fact that Leivu is genuine South Estonian also means that it is much more closely related to the other South Estonian dialects than to, say, Salaca Livonian. Note that Leivu and Salaca Livonian also share areal similarities (Pajusalu et al. 2009), which are due less to direct contacts than to their common Latvian superstrate. In any case, Leivu seems to have been the southernmost periphery of the South Estonian language area as early as the Middle Ages and perhaps even earlier. As far as I can see, this does not at all contradict archaeological and other non-linguistic evidence but quite the contrary (see now Valk 2018).

Needless to say, the concept of autochthony no longer has the same meaning as it did during the heyday of Continuity Theory. As the Uralic language family was a Bronze Age newcomer to the Baltic Sea region (Kallio 2006; Lang 2018), Leivu is no exception. The splitting up of Proto-Finnic into Inland and Coastal Finnic (viz. South Estonian vs. the rest) can be seen in the Middle and Late Iron Age archaeological evidence (cf. Tvauri 2012: 321-325). Although Inland Finnic did not diversify until more recently, there is no reason to think that its area was limited to southern Estonia, because small dialect areas typical of Estonian but atypical of Finnish were no doubt due to serfdom binding peasants to their land but only from the Middle Ages onwards.

The idea of autochthonous Leivu was also supported by many Leivus themselves, although Heikki Ojansuu (1912: 8-18) understandably did his best to downplay all such auricular traditions (already mentioned by Sjögren 1850: 9). In any case, this is what Ojansuu was personally told in Ilzene on 19 April 1911, as documented in his handwritten notes never meant to be published, thus explaining his somewhat unpolished style: 
“Täkäläiset ihmiset sanovat kieltään 'liivin kieleksi' ja 'maan kieleksi' (virolaisia eivät sano olevansa). Maan alkuasukkaita ovat muka. Taistelussa lättiläisten, myöhempien tulokkaiden kanssa, joutuivat tappiolle. Viimeksi tulivat saksalaiset." [The people here call their language "Livonian" and "Land" (they do not say they are Estonians). They are allegedly the aborigines of the land. They were defeated in the battle against the more recent Latvian newcomers. The Germans came last.]

Of these two self-designations, maakiil dates to much earlier going back to South-Central Finnic *maan 'land' (GEN) + *keeli 'language' $>$ Votic maatšeeli, Estonian maakeel, Võro maakiil (cf. also Livonian $m \bar{c} k \bar{l}$ l not meaning 'Livonian' but 'Latvian'; Kettunen 1938: 229). ${ }^{13}$ In turn, leivu (< liivu) was only recently borrowed from Latgalian leivu $(<\operatorname{li} v u)$, the genitive of leivis ( $<$ lìvis) 'Leivu' ( $<$ 'Livonian'). Latgalian leivis, Latvian līvis, etc. were in turn borrowed from German Live 'Livonian' itself derived from Middle Low German where intervocalic $b>v$. A similar spirantisation also took place in Old Norse in which the word for 'Livonian' was an even earlier borrowing than in Middle Low German (cf. the 11th century Runic Swedish [a] lf:lanti, aliflainpi 'in Livonia'; NB. there was no $v$-rune in the Younger Futhark). Therefore, the word for 'Livonian' originally had $b$ (cf. Salaca Livonian $l i \bar{b}$, Latvian lībis, Old East Slavic либь), whereas the forms with $v$ were mediated through German(ic) (cf. Courland Livonian līvõz, Estonian liivi, Medieval Latin livones, etc.). ${ }^{14}$ This being the case, the suggested etymologies presupposing original $* v$ must be rejected (cf. Grünthal 1997: 250-253, Koski 2001: 535-537, Viitso 2009: 270-273).

13 The only North Finnic speakers calling their language maa are those of the Kukkuzi dialect (Posti 1980: XVIII, 267). Incidentally, I no longer agree with myself that "Kukkuzi Votic (...) should rather be called Kukkuzi Ingrian/Izhorian" (Kallio 2014: 162). Instead, I agree with Tiit-Rein Viitso that "Kukkuzi Votic was originally a North Fennic dialect that was first influenced by Votic proper and later by Lower Luga Ingrian" (Viitso 1998: 99).

14 The forms with $v$ in classical sources (cf. Pliny Hilleviones, Tacitus Lemovii, Ptolemy $\Lambda \varepsilon v \dot{\omega} v o l / \Lambda \varepsilon v \tilde{\omega} v o l$, etc.) are no more than random similarities. In general, desperate attempts to find Finnic and other Uralic tribes in classical sources belong to Gothicism rather than serious historiography. As Proto-Finnic had not even been diversified at the beginning of our era, there could have been no Livonians either. Thus, the earliest certain attestations of the word for 'Livonian' do not occur until the early second millennium (cf. Grünthal 1997: 245-250, Koski 2001: 537-541, Ernits 2014). 
The fact that the Leivus came to be called Livonians is no wonder when we remember that now even the Low Latvian dialect is generally called Livonian in Latvian dialectology. As a matter of fact, when lingua Liuonica was for the first time mentioned in literature, it was already used to refer to Latvian spoken circa Rigam (Münster 1550: 789). The Leivus, too, were called Livonians long before they themselves used this term. Hence, there is no reason to ridicule them for regarding themselves as Livonians rather than Estonians, because the mistake was not theirs in the first place. Contrary to what especially Ojansuu was hinting between the lines, the fact that the Leivus called themselves Livonians does not make their oral tradition any less credible.

\section{Acknowledgements}

I would like to thank Liis Ermus and Karl Pajusalu for kindly providing me with lots of unpublished Leivu materials.

\section{References}

Aikio, Ante. 2006. New and Old Samoyed Etymologies (Part 2). Finnisch-Ugrische Forschungen 59. 9-34.

Aikio, Ante. 2015. The Finnic 'Secondary e-Stems' and Proto-Uralic Vocalism. Journal de la Société Finno-Ougrienne 95. 25-66. https://doi.org/10.33340/susa.82642.

Ariste, Paul. 1962. Mõni sõna leivudest. Etnograafiamuuseumi aastaraamat 18. 266-275.

Dahl, Östen \& Maria Koptjevskaja-Tamm. 2001. The Circum-Baltic Languages. In Östen Dahl \& Maria Koptjevskaja-Tamm (eds.), The Circum-Baltic Languages I: Past and Present (Studies in Language Companion Series 54), XV-XX. Amsterdam: John Benjamins. https://doi.org/10.1075/slcs.54.02dah.

EMS $=1994-$. Eesti murrete sõnaraamat . Tallinn: Eesti Keele Instituut.

Ernits, Enn. 2014. Personal names and denomination of Livonians in early written sources. Eesti ja soome-ugri keeleteaduse ajakiri. Journal of Estonian and FinnoUgric Linguistics 5(1). 13-26. https://doi.org/10.12697/jeful.2014.5.1.01.

Grünthal, Riho. 1997. Livvistä liiviin: Itämerensuomalaiset etnonyymit (Castrenianumin toimitteita 51). Helsinki: Société Finno-Ougrienne.

Gutslaff, Johannes. 1648. Observationes grammatica circa linguam Esthonicam. Dorpat: Johannes Vogel.

Honkola, Terhi, Jenni Santaharju, Kaj Syrjänen \& Karl Pajusalu. 2019. Clustering Lexical Variation of Finnic Languages Based on Atlas Linguarum Fennicarum. Linguistica Uralica 55(3). 161-184. https://doi.org/10.3176/lu.2019.3.01. 
Hupel, August Wilhelm. 1780. Ehstnische Sprachlehre für beide Hauptdialekte den revalschen und den dörptschen; nebst einem vollständigen Wörterbuch. Riga: Johann Friedrich Hartknoch.

Ikola, Niilo. 1931. Eteläviron verbien persoonapäätteistä (Suomi 5:13:2). Helsinki: Suomalaisen Kirjallisuuden Seura.

Iva, Sulev. 2002. Võro-eesti synaraamat (Võro Instituudi toimõndusõq 12). Võro: Võro Instituut.

Iva, Sulev. 2007. Võru kirjakeele sõnamuutmissüsteem (Dissertationes philologiae estonicae Universitatis Tartuensis 20). Tartu: Tartu Ülikooli Kirjastus.

Iva, Sulev. 2015. Liivi, Ludzi ja Kraasna maarahva kiil. Keel ja Kirjandus 58. 515-517.

Iva, Triin. 2007. Lühiülevaade Leivu murdest ja selle uurijatest. Tartu Ülikooli LõunaEesti keele- ja kultuuriuuringute keskuse aastaraamat 6. 11-18.

Junttila, Santeri. 2018. Mille maq kiŕoda nõgahn astmõhn aq saq kiŕotat tugõvahn? In Jüvä Sullõv (ed.), Valitsõmisjaotusõst keeleaoluuni (Võro Instituudi toimõndusõq 33), 107-117. Võro: Võro Instituut.

Kallio, Petri. 2006. Suomen kantakielten absoluuttista kronologiaa. Virittäjä 110(1). $2-25$.

Kallio, Petri. 2007. Kantasuomen konsonanttihistoriaa. In Jussi Ylikoski \& Ante Aikio (eds.), Sámit, sánit, sátnehámit: Riepmočála Pekka Sammallahtii miessemánu 21. beaivve 2007 (Mémoires de la Société Finno-Ougrienne 253), 229-249. Helsinki: Société Finno-Ougrienne.

Kallio, Petri. 2012. The Non-initial-syllable Vowel Reductions from Proto-Uralic to Proto-Finnic. In Tiina Hyytiäinen, Lotta Jalava, Janne Saarikivi \& Erika Sandman (eds.), Per Urales ad Orientem: Iter polyphonicum multilingue. Festskrift tillägnad Juha Janhunen på hans sextioårsdag den 12 februari 2012 (Mémoires de la Société Finno-Ougrienne 264), 163-175. Helsinki: Société Finno-Ougrienne.

Kallio, Petri. 2014. The Diversification of Proto-Finnic. In Joonas Ahola \& Frog (eds.), Fibula, Fabula, Fact: The Viking Age in Finland (Studia Fennica Historica 18), 155-168. Helsinki: Suomalaisen Kirjallisuuden Seura.

Kallio, Petri. 2015. The Language Contact Situation in Prehistoric Northeastern Europe. In Robert Mailhammer, Theo Vennemann \& Birgit Anette Olsen (eds.), The Linguistic Roots of Europe: Origin and Development of European Languages (Copenhagen Studies in Indo-European 6), 77-102. Copenhagen: Museum Tusculanum Press.

Kallio, Petri. 2016. Historical Phonology from Proto-Finnic to Proto-Livonian. Eesti ja soome-ugri keeleteaduse ajakiri. Journal of Estonian and Finno-Ugric Linguistics 7(1). 39-65. https://doi.org/10.12697/jeful.2016.7.1.02.

Kallio, Petri. 2018a. Ensitavun diftongit kantasuomessa. In Sampsa Holopainen \& Janne Saarikivi (eds.), Perì orthótētos etýmōn: Uusiutuva uralilainen etymologia (Uralica Helsingiensia 11), 251-268. Helsinki: Société Finno-Ougrienne.

Kallio, Petri. 2018b. Vanhan kirjaeteläviron äännehistoriaa. In Jüvä Sullõv (ed.), Valitsõmisjaotusõst keeleaoluuni (Võro Instituudi toimõndusõq 33), 118-144. Võro: Võro Instituut.

Käsi, Inge. 2011. Vanapärase Võru murde sõnaraamat. Tallinn: Eesti Keele Instituut. Keem, Hella. 1970. Eesti murded III: Tartu murde tekstid. Tallinn: Valgus. 
Keem, Hella \& Inge Käsi. 2002. Eesti murded VI: Võru murde tekstid. Tallinn: Eesti Keele Instituut.

Kettunen, Lauri. 1938. Livisches Wörterbuch mit grammatischer Einleitung (Lexica Societatis Fenno-Ugricae 5). Helsinki: Société Finno-Ougrienne.

Kettunen, Lauri. 1962. Eestin kielen äännehistoria (Suomalainen kirjallisuuden Seuran toimituksia 156). ${ }^{3}$ Helsinki: Suomalaisen Kirjallisuuden Seura.

Koivisto, Vesa. 1989. Itämerensuomen refleksiivitaivutuksen ja mediaalitaivutuksen suhteesta. Virittäjä 93. 102-110.

Kont, Karl. 1954. Morfoloogiline ülevaade Leivust: Verb. Unpublished manuscript, available at emsuka.eki.ee.

Koski, Mauno. 2001. Liivinmaan nimi. Virittäjä 105. 530-560.

Laande, Alli \& Triin Todesk. 2013. Mulgi sõnastik. Tallinn: Eesti Keele Sihtasutus.

Lang, Valter. 2018. Läänemeresoome tulemised (Muinasaja teadus 28). Tartu: Tartu Ülikooli Kirjastus.

Laurosela, Jussi. 1913, 1914. Ä̈̈nnehistoriallinen tutkimus EteläPohjanmaan murteesta (Suomi 4:13:1, 4:13:2). Helsinki: Suomalaisen Kirjallisuuden Seura.

Lehtinen, Tapani. 1984. Itämerensuomen passiivin alkuperästä (Suomi 129). Helsinki: Suomalaisen Kirjallisuuden Seura.

Mela, Marjo. 2001. Latvian virolaiset: Historia, kieli ja kulttuuri (Bibliotheca Historica 69). Helsinki: Suomalaisen Kirjallisuuden Seura.

Mets, Mari, Anu Haak, Triin Iva, Grethe Juhkason, Mervi Kalmus, Miina Norvik, Karl Pajusalu, Pire Teras, Tuuli Tuisk \& Lembit Vaba. 2014. Lõunaeesti keelesaarte tekstid. (Eesti murded IX). Tallinn: Eesti Keele Instituut, Tartu Ülikool.

Münster, Sebastian. 1550. Cosmographia universalis. Basel: Henrichus Petri.

Nigol, Salme. 1955. Märkmeid matkalt leivu keelesaarele. Emakeele Seltsi Aastaraamat 1. 147-151.

Nigol, Salme. 1970. Paar sõna Leivu ja Lutsi murrakust. In Saaremaast Sajaanideni ja kaugemalegi, 62-68. Tallinn: Valgus.

Niilus, Valter. 1935. Leivu murret: Häälikutelooline ülevaade. Unpublished manuscript, available at emsuka.eki.ee.

Niilus, Valter. 1936. Leivu murret: Morfoloogiat: Verb. Unpublished manuscript, available at emsuka.eki.ee.

Niilus, Valter. 1939. Ülestähendusi leivu murdest: L. Kettuneni märkmeist välja kirjutatud. Unpublished manuscript, available at emsuka.eki.ee.

Nikkilä, Osmo. 1985. Apokope und altes Schriftinnisch: Zur Geschichte der i-Apokope des Finnischen. Groningen: Drukkerij van Denderen.

Ojansuu, Heikki. 1912. Virolaiset siirtokunnat lättiläisalueella, niiden lähtöpaikka ja -aika. Suomalainen Tiedeakatemia: Esitelmät ja pöytäkirjat 1912. 7-26.

O'Rourke, Patrick \& Karl Pajusalu. 2016. Livonian features in Estonian dialects. Eesti ja soome-ugri keeleteaduse ajakiri. Journal of Estonian and Finno-Ugric Linguistics 7(1). 67-85. https://doi.org/10.12697/jeful.2016.7.1.03.

Pajusalu, Karl. 1996. Multiple Linguistic Contacts in South Estonian: Variation of Verb Inflection in Karksi. (Turun yliopiston suomalaisen ja yleisen kielitieteen laitoksen julkaisuja 54). Turku: Turun yliopisto. 


\section{Petri Kallio}

Pajusalu, Karl. 1999. Etelä-Viron murremaisemat uudessa valaistuksessa. Sananjalka 41(1). 145-166. https://doi.org/10.30673/sja.86610.

Pajusalu, Karl. 2006. Die südestnischen Schriftsprachen und ihr dialektaler Hintergrund. Ural-Altaische Jahrbücher: Neue Folge 20. 86-100.

Pajusalu, Karl, Eva Velsker \& Ervin Org. 1999. On recent changes in South Estonian: dynamics in the formation of the inessive. International Journal of the Sociology of Language 139(1). 87-104. https://doi.org/10.1515/ijsl.1999.139.87.

Pajusalu, Karl, Arvo Krikmann \& Eberhard Winkler. 2009. Lexical Relations between Salaca Livonian and Estonian Dialects. Linguistica Uralica 45(4). 283-298. https:// doi.org/10.3176/lu.2009.4.04.

Pajusalu, Karl, Tiit Hennoste, Ellen Niit, Peeter Päll \& Jüri Viikberg. 2018. Eesti murded ja kohanimed. 3rd ed. Tartu: Eesti Keele Sihtasutus.

Posti, Lauri. 1953. From Pre-Finnic to Late Proto-Finnic: Studies on the Development of the Consonant System. Finnisch-Ugrische Forschungen 31. 1-91.

Posti, Lauri. 1961. Itämerensuomalaisen verbitaivutuksen kysymyksiä. Virittäjä 65. 351-366.

Posti, Lauri. 1980. Vatjan kielen Kukkosin murteen sanakirja (Lexica Societatis FennoUgricae 19). Helsinki: Société Finno-Ougrienne.

Rätsep, Huno. 1989. Eesti keele tekkimise lugu. Akadeemia 1(7). 1503-1524.

Sjögren, Andreas Johan. 1850. Zur Ethnographie Livlands. Bulletin de la classe historico-philologique de l'Académie impériale des Sciences de St.-Pétersbourg VII. 1-26, 33-45, 49-70.

Stang, Christian Schweigaard. 1966. Vergleichende Grammatik der baltischen Sprachen. Oslo: Universitetsforlaget.

Tanning, Salme. 1955. Leivu morfoloogiat. Unpublished manuscript, available at emsuka.eki.ee.

Tanning, Salme. 1956. Leivu murdetekste (helilindistatud). Unpublished manuscript, available at emsuka.eki.ee.

Tanning, Salme. 1961. Mulgi murdetekstid. (Eesti murded I). Tallinn: Eesti Riiklik Kirjastus.

Teras, Pire. 2003. Lõunaeesti vokaalisüsteem: Võru pikkade vokaalide kvaliteedi muиtumine (Dissertationes philologiae estonicae Universitatis Tartuensis 11). Tartu: Tartu Ülikooli Kirjastus.

Teras, Pire. 2010. Quantity in Leivu. Linguistica Uralica 46(1). 1-16. https://doi. org/10.3176/lu.2010.1.01.

Toomse, Mihkel. 1955. Zur dritten Person Singularis im Südestnischen. Commentationes Balticae: Jahrbuch des Baltischen Forschungsinstituts 2. 1-49.

Toomse, Mihkel. 1998. Lõuna-Eesti murded 1-30: Kaardid (Turun yliopiston suomalaisen ja yleisen kielitieteen laitoksen julkaisuja 56). Turku: Turun yliopisto.

Tuomi, Tuomo, Anneli Hänninen, Vladimir Rjagojev \& Tiit-Rein Viitso (eds.). 20042010. Atlas Linguarum Fennicarum I-III. (Suomalaisen Kirjallisuuden Seuran toimituksia 800, 1295). Helsinki: Suomalaisen Kirjallisuuden Seura.

Tvauri, Andres. 2012. The Migration Period, Pre-Viking Age, and Viking Age in Estonia (Estonian Archaeology 4). Tartu: Tartu Ülikooli Kirjastus. https://doi.org/10.26530/ OAPEN_423944. 
Vaba, Lembit. 1997. Uurimusi läti-eesti keelesuhetest. Tallinn: Eesti Keele Instituut.

Valk, Heiki. 2018. Disappearance and Traces of the Finnic Population in North-Eastern

Latvia. In Ceḷā uz latviešu tautu: Rakstu krājums (Latvijas Nacionālā Vēstures Muzeja Raksti 24), 96-114. Rīga: Latvijas Nacionālais Vēstures Muzejs.

Viitso, Tiit-Rein. 1998. Fennic. In Daniel Abondolo (ed.), The Uralic Languages, 96-114. London: Routledge.

Viitso, Tiit-Rein. 2003. Rise and Development of the Estonian Language. In Mati Erelt (ed.), Estonian Language (Linguistica Uralica: Supplementary Series 1), 130-230. Tallinn: Estonian Academy Publishers.

Viitso, Tiit-Rein. 2009. Livonian and Leivu: Shared Innovations and Problems. Linguistica Uralica 45(4). 269-282. https://doi.org/10.3176/LU.2009.4.03.

Voolaine, Paul \& Valter Niilus. 1936. Leivu fonograafilisi tekste. Unpublished manuscript, available at emsuka.eki.ee.

Wastne Testament. 1686. Meije Issanda Jesusse Kristusse Wastne Testament. Riga: Johann Georg Wilcken.

Wiedemann, Ferdinand Johann. 1861. Joh. Andreas Sjögren's livisch-deutsches und deutsch-livisches Wörterbuch. St. Petersburg: Kaiserliche Akademie der Wissenschaften.

Wiedemann, Ferdinand Johann. 1864. Versuch ueber den Werroehstnischen Dialekt. St. Petersburg: Kaiserliche Akademie der Wissenschaften.

Wiedemann, Ferdinand Johann. 1868. Die Ehsteninseln in den lettischen Kirchspielen Marienburg und Schwaneburg in Livland. Bulletin de l'Académie Impériale des Sciences de St. Pétersbourg XIII. 497-524.

Wiik, Kalevi. 1999. Etelä-Viron murrerajat Toomse-Pajusalun karttojen valossa. In Karl Pajusalu \& Tõnu Tender (eds.), Õdagumeresoomõ veeremaaq. (Võro Instituudi Toimõtiseq 6), 93-114. Võro: Võro Instituut.

Winkler, Eberhard \& Karl Pajusalu. 2009. Salis-livisches Wörterbuch (Linguistica Uralica: Supplementary Series 3). Tallinn: Estonian Academy Publishers.

Ylikoski, Jussi. 2016. The Origins of the Western Uralic $s$-Cases Revisited: Historiographical, Functional-typological and Samoyedic Perspectives. Finnisch-Ugrische Forschungen 63. 6-78. https://doi.org/10.33339/fuf.86120.

Kokkuvõte. Petri Kallio: Leivu asend. Leivut on üldiselt ühendatud võro keelega ja eriti Hargla murrakuga. Paraku need klassifikatsioonid on alati tuginenud pindsete sünkroonsete sarnasuste arvestamisele, mitte rangele diakroonilisele analüüsile. Siinne lähem vaatlus näitab, et leivu on esimesena lahknenud lõunaeesti keeleühtsusest ning selle sarnasusi Hargla võro keelega saab seletada pigem geograafilise lähedusega.

Märksõnad: ajalooline keeleteadus, läänemeresoome keeled, lõunaeesti, võro, leivu 